\title{
TBL Through Music to Foster Students' Lexical Competence
}

\section{Aprendizaje basado en tareas a través de la música para fomentar la \\ competencia léxica de los estudiantes}

\section{Luisa Fernanda Ladino Herrera}

Universidad el Bosque, Bogotá, Colombia

lladinoh@unbosque.edu.co

\section{Geraldyne Pérez Molina}

Universidad el Bosque, Bogotá, Colombia

gperezm@unbosque.edu.co

\section{Heiryn Dayanne Hernández Prieto}

Universidad el Bosque, Bogotá, Colombia

hhernandezp@unbosque.edu.co

\section{Paula Andrea Gomez Villalba}

Universidad el Bosque, Bogotá, Colombia

pgomezv@uelbosque.edu.co

Received: April 29, 2020

Accepted: August 28, 2020

How to cite this article (APA, 7th ed.):

Ladino, L. F., Pérez, G., Gomez, P. A., \& Hernández, H. D. (2020). TBL through music to foster students' lexical competence. ENLETAWA Journal, 13(2), 74-93. 


\section{Abstract}

The topic of this qualitative action research was to evidence how Task Based Learning (TBL) through music could foster students' lexical competence in a multi grade school based on "Escuela Nueva". The population of the research was a primary school of a public institution that had difficulties in their lexical competence. The goal of this research was to explore the impact that Task Based Learning through music had on students' lexical competence in an environment of "Escuela Nueva". The instruments to gather the data were field notes, videotape recordings, pictures, and questionnaires. Findings of this study evidenced that this type of musical tasks can foster lexical competence and engage students to participate actively in class. Likewise, results showed that students were able to relate and recognize words, thanks to the implementation of musical activities as well as the fact that practicing vocabulary with songs can become a good strategy to develop students' higher level of comprehension.

Keywords: Escuela Nueva, Lexical Competence, Task Based Learning through music

\section{Resumen}

El tema de esta investigación acción cualitativa fue evidenciar cómo el aprendizaje basado en tareas a través de la música podría fomentar la competencia léxica de los estudiantes en una escuela multigrado cuyas clases están basadas en "Escuela Nueva". La población de la investigación fue una escuela primaria de una institución pública que tenían dificultades en su competencia léxica. El objetivo de esta investigación es explorar el impacto que el aprendizaje basado en tareas a través tiene en la competencia léxica en un entorno de "Escuela Nueva". Los instrumentos para recopilar los datos fueron notas de campo, grabadora de vídeo cámara digital y cuestionarios. Los hallazgos de este estudio evidenciaron que este tipo de tareas musicales pueden fomentar la competencia léxica e involucrar a los estudiantes para participar activamente en clase. Del mismo modo, los resultados mostraron que los estudiantes fueron capaces de relacionar y reconocer palabras, gracias a la implementación de actividades musicales, así como practicar vocabulario con canciones puede convertirse en una buena estrategia para desarrollar en los estudiantes altos niveles de comprensión.

Palabras clave: Aprendizaje basado en tareas a través de la música, Competencia léxica, Escuela nueva 


\section{Introduction}

For the following project, we decided to work with music and songs and their possible use in language teaching. We believe that working with songs helps create a sense of receptiveness among students. Therefore, we wanted to explore the effects of music on second language students' lexical competence. This study was developed under three main constructs, which were task-based learning (TBL) through music, Lexical Competence, and Escuela Nueva/Escuela Activa. Ellis (2013) claimed that "Tasks are work plans that provide learners with the materials they need to achieve an outcome specified in communicative rather than linguistic terms" (p. 16), and music can bring variety to the everyday classroom routine (Millington, 2011). The second construct, lexical competence, is explained as "all the words in a language, the entire vocabulary of a language. Lexical knowledge is central to communicative competence and to the acquisition of a second language" (Schmitt, 2000, p. 55). The third element, which is the educational model called Escuela Nueva or Escuela Activa, "consists of offering the five degrees of the elementary school, with multigrade schools with one, two or up to three teachers in the rural areas of the country" (MEN, 2002).

For this project, we worked with primary school students from a public institution in Saboyá, Boyacá. We studied the impact that musical tasks had on lexical competence in an Escuela Nueva environment. This article is composed of five sections, and it is organized as follows: introduction and statement of the problem, literature review, research methodology, data analysis, and conclusions.

\section{Statement of the Problem}

The population for our research study was focused on students in third, fourth, and fifth grade at a public school. The students demonstrated weaknesses in their vocabulary acquisition. Due to their low English level, the learners were not able to develop activities without the support of their teacher. Additionally, the students did not have total immersion English classes, which could be one of the reasons why their English learning outcomes were lower than average. As a result, the students seemed to be reluctant to develop tasks, and they tended to avoid activities related to expressing ideas due to a lack of vocabulary in English. In brief, their

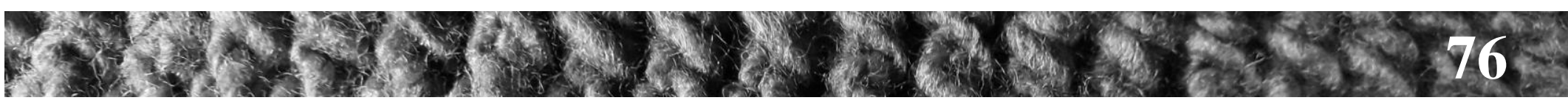


learning development was being affected by a lack of a constant English process in the classroom, thereby, making language acquisition a rare achievement.

The issue stated and described before was identified through a needs analysis that we applied in different sessions. We carried out different actions to corroborate that there was an issue with students' lexical competence in the English classes. Hence, we employed preliminary observations, class activities, discussions, and diagnostic tests to address the main problem that would be the focus of this study. All of these implementations showed us that the students had a lack of knowledge in basic vocabulary and pronunciation. However, they displayed other strengths like interest, attendance, and fellowship when it came to learning a foreign language.

As mentioned previously, we considered three main aspects that support our research study. In terms of TBL, Nunan (2006) pointed out that tasks are an important part of the classroom since students become involved in a communicative way. Also, tasks help students apply the language itself, and the adaptation of music is an opportunity to stimulate students' learning. The second aspect, lexical competence, is explained by Caro and Rosado (2017) as the basis of vocabulary that is presented and practiced in context through listening and speaking activities. Thus, students can enhance the use of words in their everyday learning environments. Finally, the Ministerio de Educación Nacional, or the Colombian Ministry of Education, claims that Escuela Nueva/Escuela Activa is a flexible model in which students are able to make a meaningful learning process while interacting with notebooks that offer activities for both teachers and learners.

\section{Research Question and Objective}

What is the impact of implementing TBL through music in a context of Escuela Nueva/Escuela Activa for third, fourth, and fifth graders of primary school?

To explore the impact that TBL has through music among third, fourth, and fifth graders in an Escuela Nueva/Escuela Activa environment.

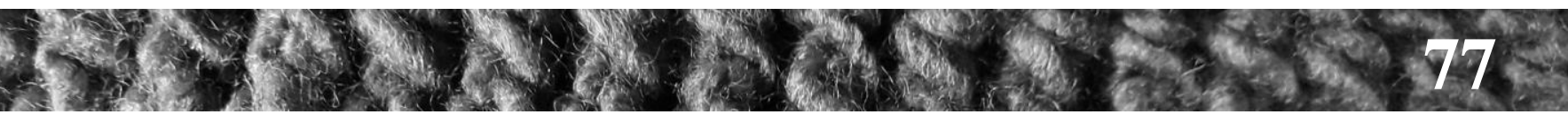




\section{Literature Review}

In this study, we have taken into consideration theoretical concepts and constructs that helped support our research study. The three constructs that are explained in this research article are: Escuela Nueva/Escuela Activa, task-based learning through music, and lexical competence. These constructs were the principal axes of our study due to their connection to the main issues we found among the primary school students.

\section{Escuela Nueva / Escuela Activa}

Escuela Nueva/Escuela Activa is an educational model aimed primarily at rural areas with diverse populations. This school model is well known in Colombia, and it has expanded to urban settings as well. In Escuela Nueva/Escuela Activa, multi-grade learners have one teacher who is in charge of all the subjects (MEN, 2006). Additionally, Escuela Nueva/Escuela Activa functions under a participative work methodology among teachers and students in which teachers consider their students' needs, interests, expectations, learning and cognitive styles. It is important to note that the students' level of education vary greatly in one classroom. Escuela Nueva/Escuel Activa stimulates students' individual and group environment by enhancing their self-confidence and self-worth, so that they can learn at their own pace and with their own styles.

The learning process occurs within each student with their own individual characteristics. In Flores' (2010) words, learners build their own learning tools, which involve the conceptual and moral components that allow them to support their internal development. In that sense, Escuela Nueva /Escuela Activa is a flexible model that focuses its pedagogical process on the student as the principal objective of the teaching-learning growth. One of the issues with the educational model could be the presumption that learners will not be able to make important learning decisions with others since their achievement is individual. However, team-guided experiences could help stimulate social construction with all grade levels, as well as enhance students' capacities to contribute to a more inclusive society.

As for the model's curricular strategies, it promotes the implementation of notebooks for all subjects (Math, Spanish, Social Science, Natural Science, and English). The notebooks have course material that have been designed according to students' contexts. Moreover, these materials offer meaningful activities for teachers and learners, which permit them a natural 
learning and teaching process. Despite the fact that the English material is connected to the other notebooks, as well as to the Ministry of Education guidelines, the pertinent teacher training has not been provided to English teachers at the school where we did our study. Because of this, we may not see the fruitful expectations in foreign language development materialize.

To conclude, Escuela Nueva/Escuela Activa has the potential to be an effective methodology that impacts students' lives, especially because the curriculum engages the community's needs. The Ministry of Education has supported the foreign language learning process through material, but there is a need for professional development among teachers.

\section{TBL Through Music: An Approach to Musical Tasks}

Task-based learning (TBL) can promote communication in a significant way inside the classroom in terms of language. As Richards and Rodgers (2004) stated, TBL is "engaging learners in task work provides a better context for the activation of learning processes" (p. 223). By implementing TBL, students can have the ability to naturally acquire a second language, bearing in mind students' real context. In addition, TBL aims at increasing independency and autonomy in students' language learning process. For these reasons, the integration of TBL to learn a foreign language is useful to learn proper communication with both teachers and students.

Nowadays, songs are fruitful tools that can be used in the second language classroom, and they contain many benefits, such as creating a positive learning environment and increasing interest and motivation. As Shen (2009) claimed, "motivation is vital in language learning and it can be triggered by internal causes such as the learner's interest, enthusiasm and desire or by external influences such as peer pressure" (p. 90).

According to the definition of TBL presented before, implementing Task-based learning through music can activate students' knowledge and interests in the foreign language learning process. Paquette and Rieg (2008) affirmed that songs have the power to transform the classroom into a positive learning environment, where children can excel academically, socially, and emotionally. Working with music and tasks expand the opportunities to memorize linguistic details, and this enables students to reinforce their knowledge acting frequently in different and real situations. 


\section{Research Design}

Our research proposal was situated as an action research. Action research is defined as "a systematic process of solving educational problems and making improvements" (Tomal, 2010, p. 10). Our inquiry was based on proving and supporting theory through different activities. For that reason, it was a qualitative approach since it allowed us to discover situations and possibilities in a specific environment that could support theory and vice versa. According to Bengtsson (2016), qualitative research helps the researcher understand his or her participants in a given context or situation. Additionally, qualitative research is generally used to address the problems that occur in a specific educational environment (Tomal, 2010). In using action research under a qualitative paradigm, we were able to implement various data collection instruments to analyze the educational situation. We could then understand the connection the activities had with our study, while attempting to understand a real-world environment.

\section{Context and Population}

The context selected for the application of our project was a rural school located in Saboyá, Boyacá, in which the learning process is based on the methodology known as Escuela nueva/Escuela activa. This is a multilevel school, and the teacher needs to manage six grade levels at the same time using different skills, such as autonomy and teamwork.

Our project was developed with a population of 38 students who are between the ages of 4 and 12 years old. They are divided into six different groups (preschool, first, second, third, fourth, and fifth grade). These grades are separated into two classrooms. Each classroom has three grade levels. The first classroom has preschool, first, and second grade. The second classroom is for third, fourth, and fifth grade, which were the participants for this study.

The main purpose of this research study was to strengthen the students' lexical competence according to the English as a foreign language learning process. For this reason, we decided to work with this population due to the weaknesses we noticed in the needs analysis. Therefore, we considered that our research proposal could be useful to help the students in terms of vocabulary. We used musical tasks to promote the students' development in their lexical competence, which would hopefully help them with learning a foreign language.

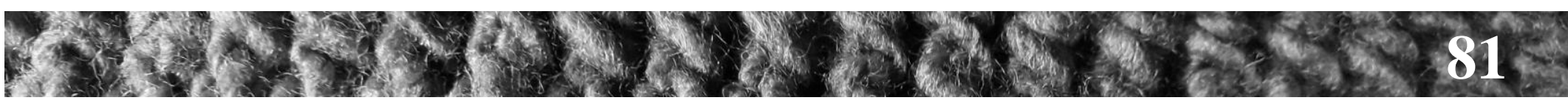


During the research study, the students developed different activities with music as the main resource in order to improve their lexical competence. In each class, the teacher used a song related to the daily topic. The students would perform group activities, worksheets, and presentations to practice vocabulary previously identified in the songs.

\section{Ethical Considerations}

Due to the agreement between the Escuela Normal Superior de Saboyá and our university, we informed the institution about the investigation we were carrying out before, during, and after the process. The participants were also given information about the study. Each student received a consent form, which their guardians signed because the participants were underage. The students' participation was optional, and it did not affect their grades. Additionally, the law that protects our participants is called "Ley Nacional de Protección de Datos" (law number 25.326), and data confidentiality is guaranteed. Moreover, no one was paid to participate in this study, and the participants identities, such as their names and faces, will not be published.

\section{Instruments for Data Collection}

A variety of data collection methods are available, but it is crucial to select appropriate instruments that are relevant to each research study to ensure that the data are accurate. Tomal (2010) suggested that four basic factors - namely who, what, where and how - should be emphasized when designing data collection instruments.

As for the characteristics of the participants, the methods of data collection could depend on the number of students, their ages, and their grade level. In our case, there was only one classroom teacher, whose duty was to supervise our teaching during the classroom sessions. According to our research and the problem that has been addressed, we selected three instruments that were suitable for data collection. These instruments allowed us to support and validate the research project that we carried out.

1. Transcripts of video recordings: This instrument was used to obtain visual material of the total teaching situation. It was an aid to diagnose and provide evidence, and a means of examining in detail a specific teaching situation or episode.

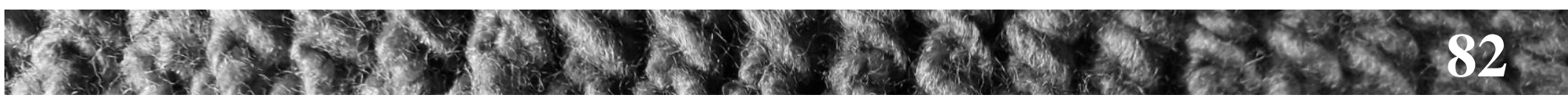


mentioned previously, we focused on using TBL. However, music has been used with other methods like Total Physical Response, or TPR, which associates physical movements with language instruction. Pollatschek and Hagen (1996) stated that "research has shown that students who are engaged in movement activities, show superior academic skills and have a more positive attitude towards school" (p. 45). Based on our study, it was apparent that the population demonstrated more effective results in their lexical competence when we used music. The participants felt that it provided them with an interesting and comfortable environment for their English learning process.

Day by day, the learners seemed more engaged in their English classes, and we noticed improvements in their process. As they sang the songs during the task, their self-confidence seemed to increase, especially when they began to master the English words and expressions in the lyrics. According to Medina (2002), singing and listening to music can be a pleasant experience for learners. Thereupon, the following examples demonstrate how the use of music helped students learn and enrich their lexical competence: The first excerpt comes from the video recording in the second session of class. Student 2 reflects on the learning process below:

\section{Example 1}

Min 5:48 - 6:09

Teacher: Everybody give me the papers, please.

ST: ¡Teacher mira! -y me lo aprendí gracias a las canciones!

Teacher: What did you learn with the help of the songs?

ST: ¿Qué? ah, ummm, pues las partes del cuerpo teacher, eso que acabamos de hacer en la hoja. Teacher: GREAT! (Transcript of Video Recording 3, Session 2, Student 2)

The next example came from our field notes. The song helped the students remember prior knowledge about the topic in the "pre" stage of the task. As noted in the figure, the song helped students feel comfortable to speak about their own background knowledge. 


\section{Example 2}

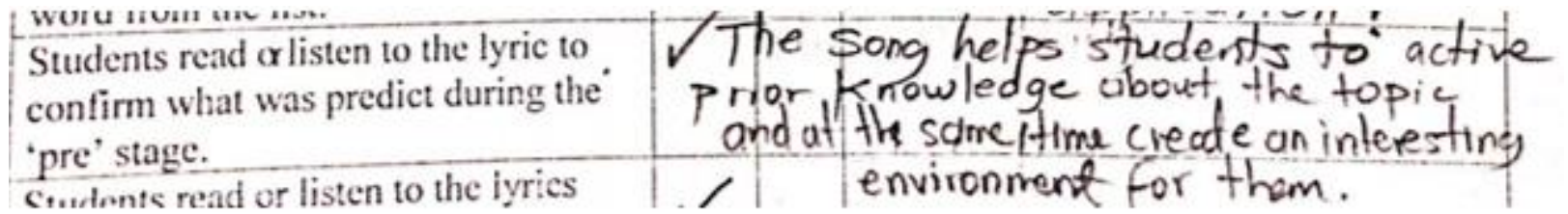

(Field Notes 3, Session 3, Student 13)

The third example also came from our field notes. The students had to use movement to learn the word. In this case, we employed aspects of TPR to the task at hand. With the use of music and movement, the students were more motivated to participate in class than when we first did the needs analysis.

\section{Example 3}

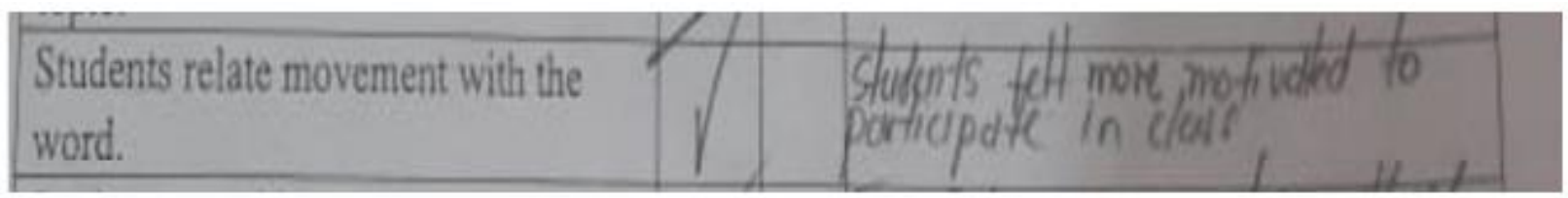

(Field Notes 3, Session 3, Student 13)

The final example in this category came from our field notes as well. Here, we observed how the students, in particular Student 8, was responsive to the song. The student was able to sing along with the music and appeared to be having fun. Additionally, Student 8 was uttering the words in order to follow along with the song. 


\section{Example 4}

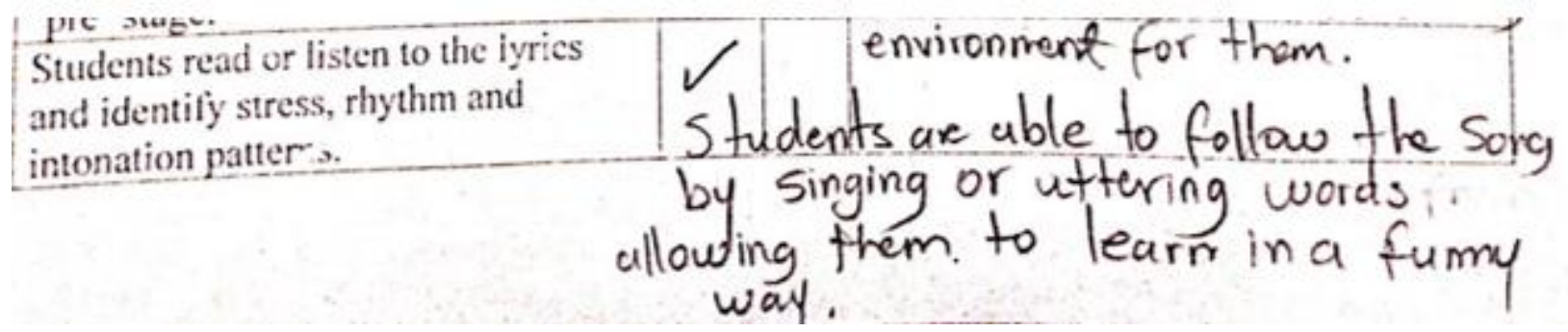

(Field Notes 2, Session 2, Student 8)

The examples presented before showed that music was an effective and enjoyable educational tool to engage and motivate learners, particularly in learning vocabulary. The first example demonstrates an answer of a student who affirmed that songs helped him learn English vocabulary. Throughout the study, it was notable that the participants were enthusiastic and found it easier to learn English by the use of music in class. The second excerpt, which was taken for our field notes, helped us understand that implementing tasks with songs could be used to introduce a topic, while creating a comfortable environment to speak. The third and fourth example helped reiterate the finding that the students were able to follow the song by uttering the words. They felt like they were having fun and learning at the same time, which created a less stressful environment for them to practice their lexical competence.

All the excerpts demonstrated that the integration of music provided more opportunities to enhance the students' lexical competence, and it acted as a suitable tool for learning anytime and anywhere working as a form of implicit learning.

Before beginning the study, the learners seemed reluctant to learning the target language because they felt they did not have enough vocabulary to express themselves. In order to enable learners to use the language confidently, music provided a basis to learn vocabulary while motivating students. The additional inclusion of sensory and visual input related to the songs helped build vocabulary acquisition and their confidence in using the foreign language (Shin, 2006).

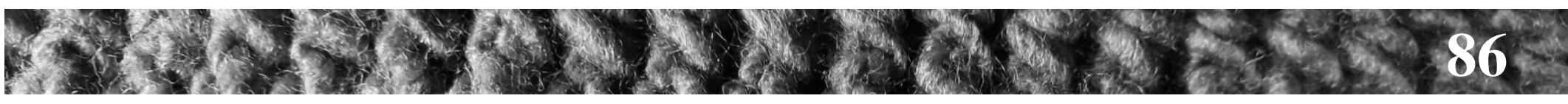




\section{Cognates: Relation Between Spanish and English Vocabulary}

A cognate is "a word in one language which is similar in form and meaning to a word in another language because both languages are related" (Richards \& Schmidt, 2002, p. 829). Vocabulary is an essential factor in students' lexical competence development. For the students, it was difficult to memorize words out of context. Additionally, the students lacked resources to individually check if they misspelled or forgotten a word.

During the study, the students became interested in finding new possibilities of expressing themselves and finding connections between Spanish (L1) and English (L2). Through the implementation of TBL through music, we noticed that the students used cognates in the lyrics to help them remember vocabulary and pronunciation. Frunza and Inkpen (2009) considered that "cognates as word pairs that are orthographically identical or have slightly different spellings" (p. 2).

The following examples demonstrated cases where students used music to help their lexical competence. The data presented were collected through three instruments: transcripts of video recordings, field notes, and questionnaires. Overall, we identified that the implementing music from the beginning of the first session helped the students increase their vocabulary knowledge and communicate easier with cognates. The singing and repetition of learned words led to active participation during the sessions. In the same way, implementing music with TBL can activate students' knowledge and interests in their foreign language learning process, instead of the one that is given from the teacher (Nunan, 2006).

Nevertheless, we want to point out several issues with false cognates, in which students assigned meaning to words based on their Spanish similarity. However, the word had a different meaning. In other situations, students made up words thinking that that was the proper spelling and pronunciation of the words in English. In order to better explain the case, the following examples provide specific situations of how the students used cognates and music to enrich their vocabulary, even if the words themselves were incorrect.

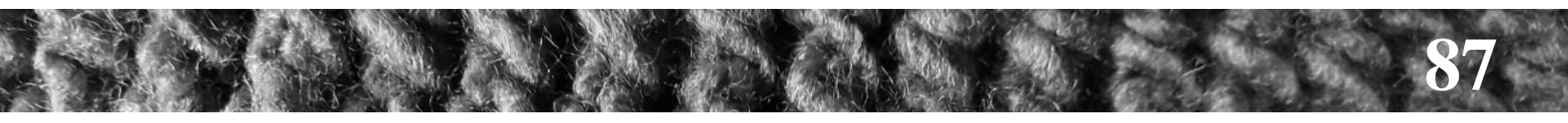




\section{Example 1}

Min 6:18- 7:05

Teacher: I'm fluffy and warm in my furry coat, I'm not a goat. I eat a lot of grass, thanks to me you can get jackets, coats. What am I?

ST: ovech

Teacher: ¿Ovech? What is Ovech?

ST: Pues Oveja teacher.

Teacher: Mmmm Ok, te entiendo. Pero, oveja en inglés es Sheep. (Transcript of Video

Recording 5, Session 6, Student 4)

\section{Example 2}

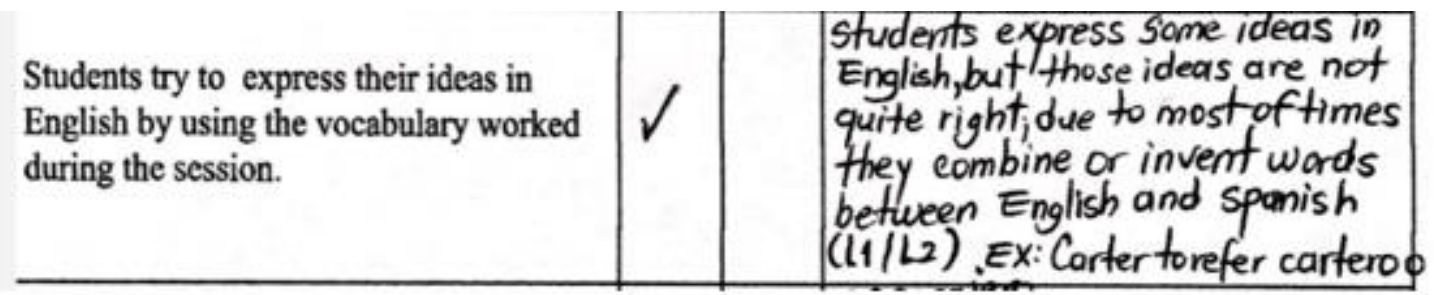

(Field Notes 6, Session 4, Student 11)

In the field notes above, we noticed that Student 11 expressed some ideas in English, but those ideas are not quite right due the combination of languages or invention of words, such as carter to mean cartero or postman.

\section{Example 3}




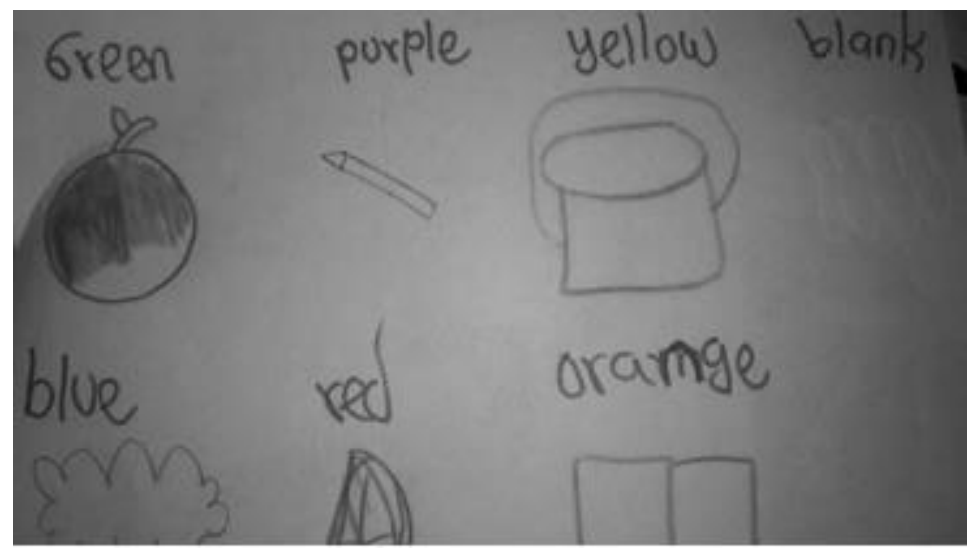

(Questionnaire 1, Session 1, Student 6)

In the example above, Student 6 had to draw an object related to the color that the teacher mentioned. The song helped reinforce the colors in English, although the missing vocabulary was substituted with a cognate "blank" by Student 6 .

The examples presented above demonstrated that the learners realized that Spanish and English share a large number of orthographic and phonological features. The first example was taken from a transcript of the video recordings. Student 4 tried to guess the name of the animal before having heard the word in the song. In fact, Student 4 used a similar word for sheep in Spanish, which is oveja. The word Student 4 created was “ovech”, instead of "sheep" in English.

The second excerpt came from our field notes. We noticed that Student 11combined English and Spanish to make up the word "carter" instead of "postman". The same is true for the final excerpt, which we collected from a students' questionnaire. This final sample illustrates the answer of a student who related "blank" with "blanco" in Spanish, but in English the correct word is white.

When reviewing these examples, we analyzed that the students made use of cognates unconsciously to express their ideas and to improve their English level. The use of cognates was imperative during the students' language learning process. Afterward, the teacher helped the students understand the differences and similarities between words in the mother tongue and foreign language. The use of music also helped students remember the correct words in the target language, as seen in the first category.

\section{Conclusions}

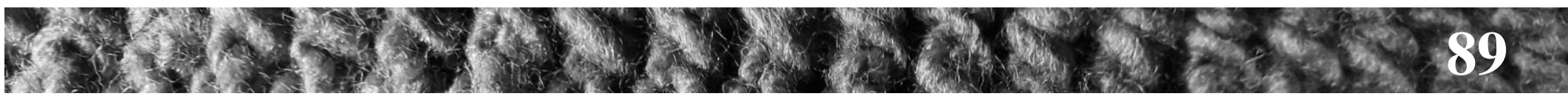


The present article explored the impact that Task-based learning through music had on the participants in an environment of Escuela Nueva/Escuela Activa with a focus on students' lexical competence. After analyzing the data collected from the instruments, we identified crucial aspects on how students are impacted by music in their process to learn new vocabulary to express themselves.

First, the students did learn new and different English words through the use of songs in the assigned tasks. They were able to apply these new words in their learning contexts, express themselves, and practice the knowledge acquired. Second, the students seemed interested to learn with music. In some cases, they tried to link their prior knowledge in Spanish to guess words the correct words in English. Due to their lack of exposure to the target language, they used incorrect cognates or invented words. From the literature, we found that the use of cognates is a common error among language learners when a lack of vocabulary knowledge is present. However, music can provide language learners with an exposure to vocabulary. A learner may be better equipped to identify their errors after performing tasks with motivating songs. In this study, the use of music fostered the lexical competence, and vocabulary acquisition improved. Over the duration of the study, we noticed that the use of false cognate or invented words diminished. Therefore, the students were able to remember vocabulary in a much better way than before we started the study. They showed more confidence when expressing themselves due to their increase in vocabulary.

\begin{abstract}
About the Authors:
Luisa Fernanda Ladino Herrera, Geraldyne Pérez Molina, Heiryn Dayanne Hernández Prieto, and Paula Andrea Gomez Villalba, are currently completing their undergraduate studies at the Universidad del Bosque in Bogotá, Colombia.
\end{abstract}

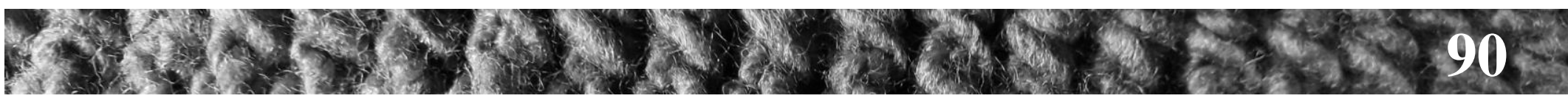




\section{References}

Awla, H. A. (2014). Learning styles and their relation to teaching styles. International Journal of Language and Linguistics, 2(3), 241-245. https://www.researchgate.net/publication/275567766_Learning_Styles_and_Their_Relati on_to_Teaching_Styles.

Baralo, M. (2005). La competencia léxica en el marco común europeo de referencia. Revista CARABELA, 58, 27-48.

Bengtsson, M. (2016). How to plan and perform a qualitative study using content analysis. NursingPlus Open, 2, 8-14.

Bravo, M. A., Hiebert, E. H., \& Pearson, P. D. (2007). Tapping the linguistic resources of Spanish/English bilinguals: The role of cognates in science. Vocabulary Acquisition: Implications for Reading Comprehension, 140-156.

Bryman, A. (2012). Social research methods (4th ed.). Oxford University Press.

Creswell, J. W. (2014). Educational research: Planning, conducting, and evaluating quantitative and qualitative research (5th ed.). Pearson/Merrill Prentice Hall.

Creswell, J. W. (2014). Research design: Qualitative, quantitative, and mixed methods approaches (4th ed.). Sage.

Calzavarini, F. (2017). Inferential and referential lexical semantic competence: A critical review of the supporting evidence. Journal of Neurolinguistics, 44, 163-189. https://doiorg.ezproxy.unbosque.edu.co/10.1016/j.jneuroling.2017.04.00.

Caro, K., \& Rosado, N. (2017). Lexis, lexical competence and lexical knowledge: A review. Journal of Language Teaching and Research, 8(2), 205-213.

Corrales Loaiza, J. C., Salazar, L., Biviana, L., Rendón Gómez, A. M., \& Caicedo González, D. C. (2018). Estrategias pedagógicas para la enseñanza del inglés en escuela nueva [Bachelor's thesis, Escuela de Educación y Pedagogía].

Ellis, R. (2003). Task-based language learning and teaching. Oxford University Press.

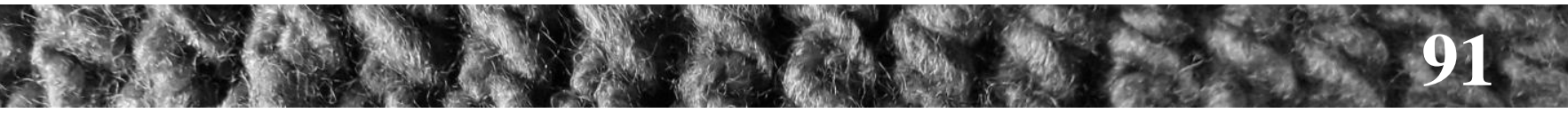


Frunza, O., \& Inkpen, D. (2009). Identification and disambiguation of cognates, false friends, and partial cognates using machine learning techniques. International Journal of Linguistics, 1(1), 1-37.

Glesne, C. (2015). Becoming qualitative researchers: An introduction. Pearson.

Holly, M. L., Arhar, J. M., \& Kasten, W. C. (2005). Action research for teachers: Traveling the yellow brick road. Pearson/Merrill/Prentice Hall.

Hopkins, D. (2014). A teacher's guide to classroom research. McGraw-Hill Education (UK).

Laver, J., \& John, L. (1994). Principles of phonetics. Cambridge University Press.

Mertler, C. A. (2013). Action research: Improving schools and empowering educators. Sage Publications.

Millington, N. T. (2011). Using songs effectively to teach English to young learners. Language Education in Asia, 2(1), 134-141.

Ministerio de Educación Nacional. Página web institucional. www.mineducacion.gov.co.

Morales Neisa, C. (2008). Using rock music as a teaching-learning tool. Profile: Issues in Teachers' Professional Development, (9), 163-180.

Narváez, Eleazar (2006). Una mirada a la escuela nueva. Educere, 10(35).

Noble, H., \& Mitchell, G. (2016). What is grounded theory? EFL Journal, 8(3), 12-18.

Orlick, T. (1988). El juego cooperativo. Cuadernos de Pedagogía, 163(1), 84-85

Paquette, K. R., \& Rieg, S. A. (2008). Using music to support the literacy development of young English language learners. Early Childhood Education Journal, 36(3), 227-232.

Pollatschek, J., \& Hagen, F. (1996). Smarter, healthier, happier. International Health, Racquet, and Sportsclub Association.

Radhakrishna, R. B. (2007). Tips for developing and testing questionnaires/instruments. Journal of Extension, 45(1), 1-4. 
Richards J. C., \& Schmidt, R. (2002). Longman dictionary of applied linguistics and language teaching. Longman.

Richards, J., \& Rodgers, T. (2004). Approaches and methods in language teaching. Cambridge: Cambridge University Press.

Ríos Beltran, R. (2013). New education and pedagogical knowledge in Colombia: Appropriation, modernity and teaching methods. First half of the 20th Century. Historia y Sociedad, (24), 79-107.

Rodríguez-Bonces, M., \& Rodríguez-Bonces, J. (2019). Task-based language learning: Old approach, new style: A new lesson to learn. Profile: Issues in Teachers' Professional Development, 12(2) 165-178. https://revistas.unal.edu.co/index.php/profile/article/view/17691/36825.

Schütz, R. (2007). Stephen Krashen's theory of second language acquisition. English Made in Brazil, 2(2), 2007.

Shen, C. (2009). Using English songs: An enjoyable and effective approach to ELT. English Language Teaching, 2(1), 88-94.

Tomal, D. R. (2010). Action research for educators. Rowman \& Littlefield Publishers. 